\title{
Marketing Mix Strategy for a Coffee Brand: Evidence from Mojokerto City, Indonesia
}

\author{
Sheila Kartikasari, Sri Tjondro Winarno, Dan Eko Nurhadi \\ Agribusiness Department, Faculty of Agriculture, Universitas Pembangunan Nasional “Veteran” Jawa Timur, Indonesia
}

\begin{abstract}
This paper attempts to show the marketing mix strategy of coffee at Cafe Budaya Kopi and Loodst Coffe, Mojokerto City. The data used in this study used a questionnaire. The sampling method used convenience sampling. The number of samples collected was 100 samples. The data analysis technique used by the researcher was descriptive statistics and inferential statistics. To analyze the data, we use Partial Least Square (PLS). SEM-PLS analysis using the outer model and inner model. The results of the study prove that Loodst Coffee and Cafe Budaya Kopi in marketing their products apply the 7P marketing mix strategy to compete in the market with other similar products. The variables of the marketing mix of product, price, place, promotion, process, people, and physical evidence get respondents' ratings in the good category. The 7P marketing mix variables partially product, price, place, promotion, process, people and physical evidence have a significant positive effect on customer satisfaction at Loodst Coffee and Coffee Culture.
\end{abstract}

Keywords: Coffee, Coffee Shop, Customer Satisfaction, Marketing Mix

\section{INTRODUCTION}

Coffee is one of the plantation commodities that play an important role in the Indonesian economy. The important contribution of the coffee commodity to the national economy is reflected in trade performance and the increase in added value. As an export product, coffee commodities can contribute in the form of foreign exchange-earners and state income, sources of income for farmers, job creation, driving growth in the agribusiness and agro-industry sectors, regional development, and environmental conservation. In addition to increasingly open export opportunities, the domestic coffee market is still quite large. The more coffee production centers in Indonesia, the greater the business competition in the coffee industry. The strata of the domestic coffee industry are now emerging and very diverse, starting from home industry-scale business units to multinational-scale coffee industries. Domestic coffee consumption is an attractive market for entrepreneurs because it still provides prospects and opportunities as well as shows conducive conditions for investing in the coffee industry. The products produced are not only to meet the needs of domestic coffee consumption but also to fill foreign markets(AEKI, 2020). The existence of increasingly fierce business competition forces business people to continue to improve product quality and be oriented to consumer and customer satisfaction.
Coffee beans can be judged quality or not starting from green beans or before the coffee beans are roasted. The more detailed attention to the quality of the coffee beans makes coffee connoisseurs also want to know more about the intricacies of coffee from being planted to the cup. The curiosity of coffee connoisseurs has made some shops take advantage of this momentum by creating a sitting area at the bar, where coffee drinkers can interact with the barista directly.

Kopi Budaya Café is a coffee shop in Mojokerto City that from the beginning wanted to educate coffee drinkers, especially second-wave connoisseurs, that coffee is not always bitter but also has a unique and complex taste. The cafe is a cafe that is quite famous in Mojokerto City and is always visited by visitors every day. Kopi Budaya Café not only sells coffee drinks but also sells local and international coffee beans of very good quality which is one of the advantages of this shop. Likewise with Loodst Coffee, one of the coffee shops in Mojokerto City that has been a pioneer since 2012 which is always visited by visitors every day because the place is quite modern for the millennial generation. Not only selling espresso but also selling packaged coffee as is the case with the Kopi Budaya Café. Based on interviews conducted by researchers with one of the employees, information was obtained that although the marketing coverage of Loodst Coffee and Kopi Budaya Café was able to reach the main market in Mojokerto City because of its strategic location, the position of the coffee brand product was only known among customers and was not very strong in the eyes of the public. consumers, meaning that there are still many consumers who are not familiar with coffee products and variants in the two coffee shops. In addition, based on initial observations regarding prices, coffee products in these two places are quite expensive when compared to other shops in Mojokerto. The two coffee shops also only rely on promotions through social media such as Instagram. This information can be used as material to evaluate and improve marketing strategies at the two coffee shops so that it is possible to attract new consumers who have the potential to become customers. For this reason, it is necessary to evaluate the coffee marketing strategy through the marketing mix attribute approach.

This aims to determine the effect of marketing mix strategy on customer satisfaction so that improvements can be made while remaining oriented to customer and customer satisfaction. 
Customers who are satisfied with a product will have a strong impression and trust in the product.The marketing mix has a set of marketing tools known as the 4Ps, namely product (product), price (price), promotion (promotion), and place (place or distribution channel). Meanwhile, in service marketing, there are several additional marketing tools such as people (people), physical evidence (physical evidence), and process (process), so it is known as the $7 \mathrm{Ps}$ (Kotler \& Keller, 2012). Based on the description above, it can be concluded that the 7P marketing mix is marketing elements that are interrelated, mixed, organized and used appropriately, so that the company can achieve effective marketing goals, while satisfying the needs and desires of consumers and customers.

The purpose of this study was to analyze, describe and explain the coffee Marketing Mix Strategy for A Coffee Brand: Evidence from Mojokerto City, Indonesia.

\section{RESEARCH METHODS}

In this research, the data analysis technique used by the researcher is to use two kinds of statistical analysis methods, namely descriptive statistics and inferential statistics. Descriptive statistics is a method of organizing, summarizing and presenting data in a formative way, while statistics is a method used to estimate population characteristics based on samples (Lind et al., 2008). This research is a quantitative research through a causal approach. Through this research, it can be seen the causal relationship between variables, including exogenous variables consisting of exogenous variables in the form of product (X1), price (X2), place (X3), promotion (X4), process (X5), people ( X6), Physical Evidence (X7), and endogenous variables in the form of Customer Satisfaction (Y).

The collection method used a questionnaire distribution technique which was directly distributed by the researcher using the google form application. The questionnaire contains questions to measure each indicator. Indicators were measured using a Likert scale, namely $1=$ Strongly Disagree (STS), 2 = Disagree (TS), $3=$ Neutral $(\mathrm{N}), 4=$ Agree $(\mathrm{S}), 5=$ Strongly Agree (SS).

The research was carried out in two places, namely Loodst Coffee, which is located on Jl. Raden Wijaya No. 50 Mojokerto City - East Java - Indonesia and the Mojokerto City Kopi Budaya Cafe which is located at Jl. Pekayon No. 59 City of Mojokerto - East Java - Indonesia. The research implementation time is from July to August 2021.

The population in this study were customers of Loodst Coffee and Kopi Budaya Cafe Mojokerto City. Questionnaires were given to customers of Loodst Coffee and Mojokerto Kopi Budaya Cafe. The sampling method used in this study is nonprobability sampling with purposive sampling technique, namely the sampling technique based on certain criteria from population members (Jogiyanto, 2014). The sampling criteria in the study were Loodst Coffee and Kopi Budaya Cafe
Mojokerto coffee customers and were willing to be interviewed using the questionnaire guide provided. Furthermore, the number of research samples was 100 samples. The number of samples obtained using incidental sampling technique

\section{III.RESULTS AND DISCUSSION}

Following are the results of data analysis and discussion of this research. Evaluation of the structural model aims to predict the relationship between latent variables in accordance with the substantial theory (Ghozali \& Latan, 2012). Evaluation of the structural model in this study was carried out by looking at the values of R-square (R2), and F-square (F2). The first inner model starts by looking at the R-Square value for each dependent variable. The value of $\mathrm{R} 2$ is used to measure the level of variation of changes in the Independent variable (Product, Price, Place, Promotion, Process, People, and Physical Evidence) on the dependent variable (Satisfaction). Based on the results of the analysis using the SmartPLS software version 3.0, the R-square on the dependent variable of consumer preferences has a value of 0.914 which means that the independent variables Product, Price, Place, Promotion, Process, People, and Physical Evidence are able to explain the dependent variable Satisfaction of $91.4 \%$ and the remaining $8.6 \%$ is explained by other variables outside the study, thus indicating the SEMPLS model in this study is "strong".

Table 1: Value of R Square (R2)

\begin{tabular}{|c|c|c|}
\hline & R Square & R Square Adjusted \\
\hline Y Satisfaction & 0,914 & 0,908 \\
\hline
\end{tabular}

Source: Smart PLS 3.0 Output (2021)

The second inner model with the F-square test (F2) which aims to see how strong the influence of exogenous constructs on endogenous constructs is. F Square is calculated as the absolute value of the individual contribution of each exogenous latent variable on the R-square value of endogenous variables. According to Hair Jr et al(2016) F Square values can be grouped into 3 categories, namely weak influence (0.02), medium effect $(0.15)$, and strong influence (0.35). The following is a table of F Square values.

Table 2: Value of F Square (F2)

\begin{tabular}{|c|c|c|c|c|c|c|c|c|}
\hline & $\begin{array}{c}\mathrm{X} 1 \\
\text { Produk }\end{array}$ & $\begin{array}{c}\mathrm{X} 2 \\
\text { Harga }\end{array}$ & $\begin{array}{c}\text { X3 } \\
\text { Tempat }\end{array}$ & $\begin{array}{c}\text { X4 } \\
\text { Promosi }\end{array}$ & $\begin{array}{c}\text { X5 } \\
\text { Proses }\end{array}$ & $\begin{array}{c}\text { X6 } \\
\text { Orang }\end{array}$ & $\begin{array}{c}\text { X7 } \\
\text { Bukti } \\
\text { Fisik }\end{array}$ & $\begin{array}{c}\mathbf{Y} \\
\text { Kepuasan }\end{array}$ \\
\hline $\begin{array}{c}\text { X1 } \\
\text { Produk }\end{array}$ & & & & & & & & 0,360 \\
\hline $\begin{array}{c}\mathrm{X} 2 \\
\text { Harga }\end{array}$ & & & & & & & & 0,335 \\
\hline $\begin{array}{c}\mathrm{X3} \\
\text { Tempat }\end{array}$ & & & & & & & & 1,882 \\
\hline $\begin{array}{c}\text { X4 } \\
\text { Promosi }\end{array}$ & & & & & & & & 0,283 \\
\hline $\begin{array}{c}\text { X5 } \\
\text { Proses }\end{array}$ & & & & & & & & 0,109 \\
\hline $\begin{array}{c}\text { X6 } \\
\text { Orang }\end{array}$ & & & & & & & & 0,507 \\
\hline $\begin{array}{c}\text { X7 } \\
\text { Bukti } \\
\text { Fisik }\end{array}$ & & & & & & & & 0,121 \\
\hline $\begin{array}{c}\text { Y } \\
\text { Kepuasan }\end{array}$ & & & & & & & & \\
\hline
\end{tabular}

Source: Smart PLS 3.0 Output (2021) 
Based on table 2 above, it can be seen that the product (X1), place (X3), and person (X6) have a strong influence in explaining the endogenous construct of satisfaction, this is because the $\mathrm{F}$ Square value of each exogenous variable is more than 0.35. Meanwhile, Price (X2) and Promotion (X4) have a medium effect in explaining the endogenous construct of satisfaction. And Process (X5) and Physical Evidence (X7) have a weak influence in explaining the endogenous construct of satisfaction.

\section{Hypothesis Testing}

Hypothesis testing is a research hypothesis testing by conducting a t-test using resampling or bootstrapping techniques that produce path coefficients. The influence between variables is considered significant at the 5\% level if the t-statistic value is greater than the t-table 1.96(Ghozali \& Latan, 2012)(Hair Jr et al., 2016)(Garson, 2012).

Table 3: Path Coefficient

\begin{tabular}{|c|c|c|c|c|c|}
\hline & $\begin{array}{c}\text { Original Sample } \\
(\mathrm{O})\end{array}$ & Sample Mean (M) & $\begin{array}{c}\text { Standard Deviation } \\
(\text { STDEV })\end{array}$ & T Statistics $(\mid \mathrm{O} / \mathrm{STDEV})$ & P Values \\
\hline X1 Produk -> Y Satisfaction & 0,683 & 0,628 & 0,239 & 0,158 & 2,860 \\
\hline X2 Harga -> Y Satisfaction & $-0,433$ & $-0,398$ & 0,119 & 9,725 & 0,004 \\
\hline X3 Tempat -> Y Satisfaction & 1,161 & 1,191 & 0,141 & 2,413 & 0,000 \\
\hline X4 Promosi -> Y Satisfaction & 0,340 & 0,337 & 0,099 & 0,016 \\
\hline X5 Proses -> Y Satisfaction & $-0,255$ & $-0,237$ & 0,169 & 3,797 & 0,010 \\
\hline X6 Orang -> Y Satisfaction & $-0,642$ & $-0,660$ & 0,053 & 2,469 & 0,000 \\
\hline X7 Bukti Fisik -> Y Satisfaction & 0,132 & 0,121 & & 0,014 \\
\hline
\end{tabular}

Source : Output Smart PLS 3.0 (2021)

Bootstrapping results in Table 3 show that all paths have a significant effect $(\mathrm{t}$ statistic $>\mathrm{t}$ table $=1.96)$ with $\mathrm{a}$ significance of 5\%. Value Testing the hypothesis about the effect of Product, Price, Place, Promotion, Process, People, and Physical Evidence on consumer satisfaction at Kopi Budaya Cafe and Loodst Coffee Mojokerto City, was carried out by observing the Path Coefficient table 3. The magnitude of the influence of the independent variable on the dependent variable can be seen from the coefficient value of each path so that the effect can be explained as follows:

\section{a. Effect of Product (X1) on Satisfaction (Y)}

Based on the results of data processing, the product independent variable has a significant effect on the dependent variable satisfaction with a t-statistic value of 2.730 greater than 1.96 and a P-value of $0.004<0.05$ so that $\mathrm{H} 1$ can be accepted. Product variable (X1) has a significant effect on satisfaction $(\mathrm{Y})$ and has a positive Path Coefficients value of 0.683 which reflects the product has a significant effect on satisfaction of $68.3 \%$. The independent variable product has a significant effect on the dependent variable satisfaction with a t-statistic value of 2.730 which is greater than 1.96 and a $\mathrm{P}$ value of $0.004<0.05$ so that $\mathrm{H} 1$ can be accepted.

\section{b. Effect of Price (X2) on Satisfaction (Y)}

The results of data processing show that the independent variable price has a significant effect on the dependent variable satisfaction with a t-statistic value of $2.860>1.96$ and a $\mathrm{P}$ Value of $0.007<0.05$ so that the $\mathrm{H} 2$ hypothesis can be accepted. Price variable (X2) has an effect on satisfaction (Y) and has a Path Coefficients value of -0.433 which reflects that price has a significant effect on satisfaction of $43.3 \%$.

\section{c. Effect of Place (X3) on Satisfaction ( $Y$ )}

The results of data processing showed that the independent variable had a significant effect on the dependent variable of satisfaction with a t-statistic value of $9.725>1.96$ and a $P$ Values of $0.000<0.05$ so that the $\mathrm{H} 3$ hypothesis was accepted. Place variable (X2) has an effect on Satisfaction (Y) and has a Path Coefficients value of 1.161 which reflects the price has a significant effect on satisfaction of $116.1 \%$.

\section{d. Effect of Promotion (X4) on Satisfaction ( $Y$ )}

The results of data processing show that the independent variable of promotion has a significant effect on the dependent variable of satisfaction with a t-statistic value of $2.413>1.96$ and a P Value of $0.016<0.05$ so that the $\mathrm{H} 4$ hypothesis can be accepted. Promotion variable (X4) has an effect on Satisfaction (Y) and has a Path Coefficients value of 0.340 which reflects that promotion has a significant effect on satisfaction of $34 \%$.

\section{e. Effect of Process (X5) on Satisfaction (Y)}

The results of data processing show that the independent process variable has a significant effect on the dependent variable satisfaction with a t-statistic value of $2.576>1.96$ and a P Value of $0.010<0.05$ so that the H5 hypothesis can be accepted. Process variable (X5) has an effect on satisfaction (Y) and has a Path Coefficients value of -0.255 which reflects the process has a significant effect on satisfaction of $25.5 \%$.

\section{f. Influence of People (X6) on Satisfaction (Y)}

The results of data processing show that the independent variable has a significant effect on the dependent variable of 
satisfaction with a t-statistic value of $3.797>1.96$ and a $\mathrm{P}$ Value of $0.000<0.05$ so that the hypothesis $\mathrm{H} 6$ can be accepted. The Person variable (X6) has an effect on Satisfaction (Y) and has a Path Coefficients value of -0.642 which reflects that people have a significant effect on satisfaction of $64.2 \%$.

\section{g. Effect of Physical Evidence (X7) on Satisfaction (Y)}

The results of data processing showed that the independent variable physical evidence had a significant effect on the dependent variable of satisfaction with a t-statistic value of $2,469>1.96$ and a $\mathrm{P}$ Values of $0.014<0.05$ so that the hypothesis H7 was accepted. Physical Evidence (X7) has an effect on Satisfaction (Y) and has a Path Coefficients value of 0.132 which reflects that people have a significant effect on satisfaction of $13.2 \%$.

\section{DISCUSSION}

Referring to the objectives and results of data analysis and research hypotheses, the following discussion can be described:

\section{Effect of Product on Satisfaction}

The results of data analysis showed that the independent variable product had a significant effect on the dependent variable of satisfaction with a t-statistic value of $2.730>1.96$ and a P Value of $0.004<0.05$ so that $\mathrm{H} 1$ was accepted. Product variable (X1) has a significant effect on satisfaction (Y) and has a positive Path Coefficients value of 0.683 which reflects the product has a significant effect on satisfaction of $68.3 \%$. The independent variable product has a significant effect on the dependent variable satisfaction with a t-statistic value of 2.730 which is greater than 1.96 and a P-value of $0.004<0.05$ so that $\mathrm{H} 1$ can be accepted. Products can compete in the market, so consumers have alternative product choices before making a decision to buy a product that has been offered (Alagöz \& Ekici, 2014). The better the quality of the products provided by Loodst Coffee and Kopi Budaya Cafe, the more customer satisfaction will be. This happened because the customers of Loodst Coffee and Kopi Budaya Cafe were satisfied with the products offered, whether it was a varied food and beverage menu, delicious taste, product innovation, hygiene, distinctive taste and so on. So that it can increase customer satisfaction Loodst Coffee and Kopi Budaya Café in Mojokerto City. The results of this study are in line with research conducted by (Dhuhita, 2017) which shows that the product has a significant effect on customer satisfaction. However, the results of this study are not in line with the research conducted (Kusumasasti et al., 2017).

\section{The Effect of Price on Satisfaction}

The results of data analysis show that the independent variable price has a significant effect on the dependent variable satisfaction with a t-statistic value of $2.860>1.96$ and a $\mathrm{P}$ Value of $0.007<0.05$ so that the $\mathrm{H} 2$ hypothesis can be accepted. Price variable (X2) has an effect on satisfaction (Y) and has a Path Coefficients value of -0.433 which reflects that price has a significant effect on satisfaction of $43.3 \%$. This positive influence can be interpreted that the perceived price suitability of customers compared to similar competitors will trigger increased customer satisfaction. So that customer satisfaction can be formed with a price that is in accordance with customer expectations. The results of this study are in line with the theory (Kotler \& Keller, 2012) which states that a price that is too high can result in no demand, but if the price is too low, the company cannot make a profit. It can be concluded that if Loodst Coffee and Kopi Budaya Cafe want to increase customer satisfaction, it is very important for Loodst Coffee and Kopi Budaya Cafe to pay attention to pricing that can compete with other similar competitors. The results of the study are in line with research conducted by (Surya, 2019) and (Muzakki, 2019) which prove that price affects customer satisfaction. In contrast to research (Dhuhita, 2017) which states that price has no effect on customer satisfaction.

\section{The Effect of Place on Satisfaction}

The results of data analysis showed that the independent variable had a significant effect on the dependent variable of satisfaction with a t-statistic value of $9.725>1.96$ and a $\mathrm{P}$ Value of $0.000<0.05$ so that $\mathrm{H} 3$ was accepted. Place variable (X2) has an effect on Satisfaction (Y) and has a Path Coefficients value of 1.161 which reflects the price has a significant effect on satisfaction of $116.1 \%$. A good location ensures quick access, can attract a large number of consumers and is strong enough to change consumer buying and shopping patterns. The location of Loodst Coffee and Kopi Budaya Cafe is strategic enough to make it easy for customers to reach. Loodst Coffee is located at Jalan Raden Wijaya No. 57 Mojokerto City. While the Kopi Budaya Cafe is located on Jalan Pekayon No.3, Mergelo, Kranggan, Kec. Kulon Soldier, Mojokerto City. So a good location will ensure quick access, can attract customers and be strong enough to change customer spending patterns and increase customer satisfaction. The results of this study are in accordance with research conducted by (Dhuhita, 2017) and (Muzakki, 2019) showing that place affects customer satisfaction.

\section{Effect of Promotion on Satisfaction}

The results of data processing show that the independent variable of promotion has a significant effect on the dependent variable of satisfaction with a t-statistic value of $2.413>1.96$ and a $\mathrm{P}$ Value of $0.016<0.05$ so that $\mathrm{H} 4$ can be accepted. Promotion variable (X4) has an effect on Satisfaction (Y) and has a Path Coefficients value of 0.340 which reflects that promotion has a significant effect on satisfaction of $34 \%$. The more intensive promotions are carried out, the more customer satisfaction will be. Promotions are used to attract consumers' purchasing power. Kopi Budaya Cafe carries out promotions through Instagram, What'sApp, Tokopedia, Grabfood and 
Gofood. Meanwhile, Loodst coffee is promoted through Instagram and WhatsApp. So that customers of the Kopi Budaya Cafe and Loodst Caffee can see discount information via Instagram and WhatsApp which will certainly increase the selling value of the product. Promotions that are carried out will certainly increase customer satisfaction in buying products. The results of this study are in accordance with research conducted by (Erdil \& Özdemir, 2016) which proves that promotion has a positive effect on customer satisfaction.

\section{Effect of Process on Satisfaction}

The results of data analysis showed that the independent process variable had a significant effect on the dependent variable of satisfaction with a t-statistic value of $2.576>1.96$ and a P Value of $0.010<0.05$ so that the H5 hypothesis was accepted. Process variable (X5) has an effect on satisfaction (Y) and has a Path Coefficients value of -0.255 which reflects the process has a significant effect on satisfaction of $25.5 \%$. These results illustrate that Loodst Coffee and Kopi Budaya Cafe have provided a good service process, but must be improved. If Loodst Coffee and Kopi Budaya Cafe make improvements to the stages or service processes that will speed up and make it easier for customers to get products, customer satisfaction will also increase. Service quality requires an assessment of the service that has been felt by the customer as a whole, while customer satisfaction is the result of service performance provided to customers (Vazifehdust \& Farokhian, 2013). Service quality still needs to be considered in the coffee shop business, because what makes customers satisfied still comes from what service providers provide to their customers. The results of this study are in line with research conducted by (Oresa Sativa, 2019) proving that the process or service quality affects customer satisfaction.

\section{People's Influence on Satisfaction}

The results of data analysis showed that the independent variable had a significant effect on the dependent variable of satisfaction with a t-statistic value of $3.797>1.96$ and a $\mathrm{P}$ Value of $0.000<0.05$ so that the hypothesis H6 was accepted. The Person variable (X6) has an effect on Satisfaction (Y) and has a Path Coefficients value of -0.642 which reflects that people have a significant effect on satisfaction of $64.2 \%$. It can be concluded that in increasing customer satisfaction, it is necessary to improve soft skills and hard skills by providing training. Employees must be friendly, polite, ethical and have good skills in providing services to customers. At Loodst Coffee and Kopi Budaya Cafe, they provide training for prospective employees, customers will certainly feel comfortable communicating with employees in the midst of busy serving orders. The results of this study are in accordance with research conducted by (Ginting \& Sembiring, 2017) which proves that people affect customer satisfaction.

\section{Effect of Physical Evidence on Satisfaction}

The results of data analysis showed that the independent variable physical evidence had a significant effect on the dependent variable of satisfaction with a t-statistic value of $2,469>1.96$ and a $\mathrm{P}$ Value of $0.014<0.05$ so that the hypothesis $\mathrm{H} 7$ was accepted. Physical Evidence (X7) has an effect on Satisfaction (Y) and has a Path Coefficients value of 0.132 which reflects that people have a significant effect on satisfaction of $13.2 \%$. Schlosser (2011) says that a customer often judges a cafe on his first impression seen from the atmosphere of the cafe in the form of layout, lighting, music, color, and layout. The results of the study are in accordance with the situation in Loodst Coffee and Kopi Budaya Cafe, that customers can feel satisfied if the physical evidence is in accordance with the wishes and comfort of the customer. The conditions for Loodst Coffee include: (1) It has a luxurious impression combined with a homey atmosphere which has two areas, namely indoor and outdoor. (2) The selection of attractive colors on the walls of the cafe. (3) Music played is able to create a feeling of pleasure according to customer needs. (4) The condition of the cafe toilet is clean. (5) Pictures and posters are in accordance with the theme of the product being sold, namely coffee and (6) Menu arrangement is carried out according to the cafe concept. (7) Ample parking space. While the Conditions of the Kopi Budaya Cafe are: (1) Minimalist design on the interior and exterior but still looks elegant around the building is the hallmark of millennial cafes and is synonymous with practicality. The choice of color combination of dark gray and beige displays the modern side of this place. (2) Entering the indoor cafe, the arrangement of benches and tables at each point varies according to the placement location points, such as the corner of the building, the street aisle, the bartender's table to a table attached to a transparent glass wall. (3) All are minimalist and compact in design. (4) The choice of wall decoration is also very concerned about the suitability of the theme in each place, it will not be the same on each side. (5) Music played is able to create a feeling of pleasure according to customer needs. (6) The condition of the cafe toilet is clean. (7) Ample parking space. The results of this study are in accordance with research conducted by Michelle (2019)and Meliani (2020), which proves that physical evidence affects customer satisfaction. The results of this study are not in line with researchconducted by and(Dhuhita, 2017) that physical evidence has no effect on customer satisfaction.

\section{CONCLUSION}

1. Loodst Coffee and Kopi Budaya Cafe in marketing their products, apply the $7 \mathrm{P}$ marketing mix strategy in order to compete in the market with other similar products. The variables of the marketing mix of product, price, place, promotion, process, people and physical evidence get respondents' ratings in the good category. The quality, taste and variety of coffee products and brands that excel at Loodst Coffee and Coffee Culture are good and in accordance with the tastes of customers and consumers. The prices offered by Loodst Coffee and Kopi Budaya Cafe are still affordable for customers. 
The location of Loodst Coffee and Kopi Budaya Cafe can be said to be strategic and easily accessible to consumers. Promotions carried out online have been going well because they take advantage of existing e-commerce. Loodst Coffee and Kopi Budaya Cafe employees have a good ability to respond to customers so as to produce a product with good quality and taste. Loodst Coffee and Kopi Budaya Cafe employees are good at providing services to customers. Loodst Coffee and Kopi Budaya Cafe are able to provide facilities that can provide a sense of comfort and pleasure to customers and consumers.

2. The 7P marketing mix variables partially product, price, place, promotion, process, people and physical evidence have a significant positive effect on customer satisfaction at Loodst Coffee and Kopi Budaya Cafe

\section{BIBLIOGRAPHY}

[1] AEKI. (2020). Aeki Aice Coffee. http://www.aekiice.org/industri_kopi_aeki.html

[2] Alagöz, S. B., \& Ekici, N. (2014). Experiential Marketing and Vacation Experience: The Sample of Turkish Airlines*. Procedia Social and Behavioral Sciences, 150, 500-510. https://doi.org/10.1016/j.sbspro.2014.09.065

[3] Dhuhita, I. P. (2017). Analisis Pengaruh Marketing MIX Terhadap Keputusan Pembelian Produk Yoghurt Menggunakan Metode Partial Least Square (PLS) Di PT. Kusumasatria Agrobio Taniperkasa Batu. Universitas Brawijaya.

[4] Erdil, T. S., \& Özdemir, O. (2016). The Determinants of Relationship between Marketing Mix Strategy and Drivers of Export Performance in Foreign Markets: An Application on Turkish Clothing Industry. Procedia - Social and Behavioral Sciences, 235(October), 546-556. https://doi.org/10.1016/j.sbspro.2016.11.067

[5] Garson, G. D. (2012). Partial least squares. In Regression and Path Modeling. Statistical Associates Publishing.
[6] Ghozali, I., \& Latan, H. (2012). Partial Least Square Konsep, Teknik, dan Aplikasi Menggunakan Program SmartPLS 3.0. Badan Penerbit Universitas Diponegoro.

[7] Ginting, P., \& Sembiring, B. K. F. (2017). Analisis Pengaruh Bauran Pemasaran Jasa Terhadap Kepuasan dengan Keputusan Memilih Sebagai Variabel Intervening (Studi Kasus pada Mahasiswa Sekolah Tinggi Ilmu Manajemen Indonesia (STIMI) Meulaboh).

[8] Hair Jr, J. F., Hult, G. T. M., Ringle, C., \& Sarstedt, M. (2016). A primer on partial least squares structural equation modeling (PLSSEM). Sage publications.

[9] Jogiyanto, H. (2014). Metode Penelitian Bisnis. Edisi Ke-6. Universitas Gadjah Mada. Yogyakarta.

[10] Kotler, P., \& Keller, K. L. (2012). Marketing Management: Philip Kotler, Kevin Lane Keller. Pearson.

[11] Kusumasasti, I., Andarwati, A., \& Hadiwidjojo, D. (2017). Pengaruh kualitas produk dan layanan terhadap loyalitas pelanggan coffee shop. Ekonomi Bisnis, 22(2), 123-129.

[12] Lind, D. A., William, G. M., \& Samuel, A. W. (2008). TeknikTeknik Statiska dalam Bisnis dan Ekonomi Menggunakan Kelompok Data Global. Salemba Empat.

[13] Meliani, K. S. (2020). PENGARUH BAURAN PEMASARAN TERHADAP KEPUASAN WISATAWAN YANG MENGINAP DI SIESTA LEGIAN HOTEL (Studi Pada Wisatawan yang Menginap di Siesta Legian Hotel). Journal Research of Management (JARMA), 1(2), 83-94.

[14] Michelle, M. (2019). Pengaruh Kualitas Layanan Dan Fasilitas Terhadap Loyalitas Pelanggan Melalui Kepuasan Pelanggan Cafe Zybrick Coffee \& Cantina. Agora, 7(1).

[15] Muzakki, A. N. (2019). Pengaruh marketing mix terhadap customer loyalty dimediasi oleh customer satisfaction: Studi kasus pada pelanggan Amstirdam Coffee Malang. Universitas Islam Negeri Maulana Malik Ibrahim.

[16] Oresa Sativa, D. (2019). Analisis Kualitas Produk, Kualitas Layanan, Dan Store Atmosphere Terhadap Kepuasan Pelanggan Coffee Shop Di Surakarta. Universitas Muhammadiyah surakarta.

[17] Surya, A. P. (2019). Customer Loyalty from Perspective Of Marketing Mix Strategy and Customer Satisfaction a Study from Grab-Online Transportation in Era of Industrial Revolution 4.0. MIX: Jurnal Ilmiah Manajemen, 9(3), 293232.

[18] Vazifehdust, H., \& Farokhian, S. (2013). Factors influencing customer satisfaction with the success factors identified in the insurance industry. African Journal of Business Management, 7(21), 2026-2032. 